\title{
MULTIMODÁLIS EGYSÉGRAKOMÁNY RAKODÁSI PROBLÉMÁINAK MEGOLDÁSA
}

\author{
Vida László \\ PhD hallgató, Miskolci Egyetem \\ Logisztikai Intézet \\ 3515 Miskolc, Miskolc-Egyetemváros, e-mail: vida@t-online.hu \\ Illés Béla \\ egyetemi tanár, Miskolci Egyetem \\ Logisztikai Intézet \\ 3515 Miskolc, Miskolc-Egyetemváros, e-mail: altilles@uni-miskolc.hu \\ Bányainé Tóth Ágota \\ egyetemi docens, Miskolci Egyetem \\ Logisztikai Intézet \\ 3515 Miskolc, Miskolc-Egyetemváros, e-mail: altagota@uni-miskolc.hu
}

\begin{abstract}
Absztrakt:
A vasúti-közúti áruszállitás térhóditásának egyik akadálya, hogy nincs hatékonyan alkalmazható egységrakomány átrakó berendezés a vasúti-közúti viszonylatban. Az ismert és széles körben alkalmazott megoldások (bakdaru, konténer targonca) látható módon nem képesek biztositani az intermodális szállitás volumenének növekedését. A szakemberek által egységesen kivánt célt, a vasútiközúti intermodális áruszállitás növekedését, egy olyan egységrakomány átrakó berendezés szolgálhatja, amely vasúti felsövezeték alatt is lehetövé teszi az egységrakományok átrakását a közúti és a vasúti fuvareszköz között. A cikkben javasolt müszaki megoldással az irodalomból ismert fizikai internet HUB-ok a hiányzó hardver eszközhöz juthatnak, kielégítve a Logisztika 4.0 követelményeket.
\end{abstract}

Kulcsszavak: intermodális vasúti-közúti áruszállitás, konténerátrakás

\begin{abstract}
:
One of the obstacles of the expansion of rail-road freight transport is the lack of efficient handling equipment on the rail-road intermodal freight transport. The known and widely used solutions (crane, container truck) do not seem to be able to increase the volume of intermodal freight transport. A transshipment device that allows the transfer of intermodal units between the road and rail transport equipment, even under the railway overhead electric line, may serve the professionals' purpose to increase the rail-road intermodal freight transport. With the technical solution proposed in this article, the physical Internet HUBs known in the literature can get the missing hardware device, what meet Logistics 4.0 requirements.
\end{abstract}

Keywords: intermodal rail-road freight transport, container transhipment 


\section{Bevezetés}

A vasúti és közúti kombinált áruszállítás problémáinak vizsgálatára a szakirodalomban számos elemzés található. A talán legfontosabb kérdések ezzel kapcsolatban a konténerkezelésre és a termináli hálózatra vonatkoznak. A szárazföldi vasúti-közúti intermodális szállítás egyik előfeltétele egy viszonylag sürü konténer terminálhálózat megléte, fejlett konténerkezeléssel [1,2]. A szakértők következtetései szerint a vasúti áruszállítás jelentős versenyhátrányban van a tiszta közúti áruszállítással összehasonlítva, melyet a vasúti szállítás rugalmatlansága okoz.

Ebben a cikkben áttekintjük az ismert és kevésbé ismert konténerkezelési technológiákat, melyeket annak ismeretében értékelünk, hogy az európai vasúti hálózat a föbb vonalakon 100\%-ban villamosított. Ennek következtében a különbözö konténeres egységrakományok vasúti szállításának előfeltétele a konténerek vasúti felsővezeték alatti átrakása az egyik szállító eszközről a másikra.

$\mathrm{Az}$ intermodális közúti-vasúti áruszállítást gyakran említik az európai közlekedési rendszer fenntartható irányú, elsődleges prioritású fejlesztésének [3]. Ezek az előzmények indokolják a kérdés napirenden tartását, illetve minél mélyrehatóbb, tudományos igényü vizsgálatát.

\section{A széles körben alkalmazott konténer átrakási technológia}

Az alábbi példák a kontinentális konténer terminálokon alkalmazott leggyakoribb konténerkezelési eljárásokat szemléltetik. Az egyes technikai megoldások hátrányait az ideálisnak tekintett konténer átrakási eljáráshoz viszonyítva adjuk meg.

$\mathrm{Az}$ 1. és 2. ábrákon bemutatott széles körben használt konténerkezelési eljárásokat függőleges átrakodásnak nevezzük a viszonylag nagy emelési magasság miatt.

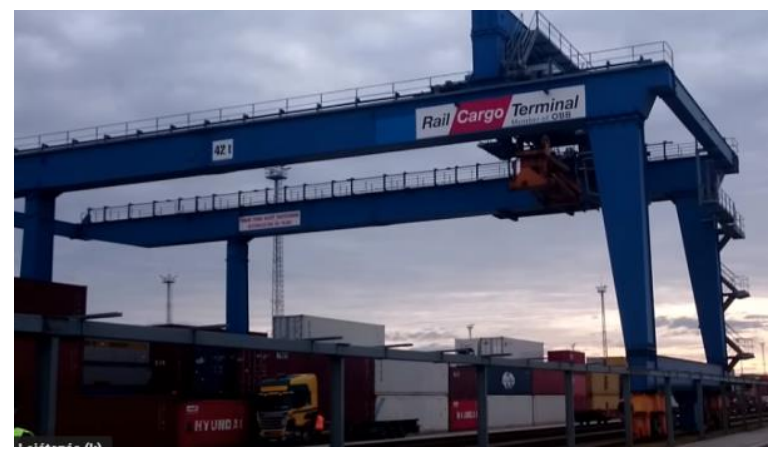

1. ábra Hiddaru [4]

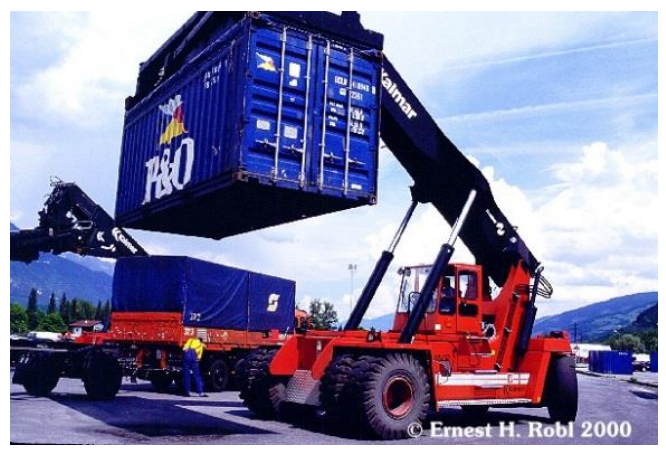

2. ábra Oldalrakodó [5]

Az 1. ábrán látható híddaru esetében hátrányként a magas beruházási költséget és a forgalom koncentrációt szükséges kiemelni. A 2. ábrán bemutatott oldalrakodónál a nagyteherbírású térbeton igény, a dízel üzem és a nagy területigény fogalmazható meg hátrányként.

$\mathrm{Az}$ ismert függőleges konténerkezelés hátránya, hogy nem alkalmazhatók elektromos vasúti felsővezeték esetén. Ez a tulajdonság negatív hatással van az intermodális áruszállítás fejlődésére. A vasúti-közúti intermodális áruszállítás időbeli versenyhátrányát, különösen rövidebb távolság esetén (kevesebb, mint $300 \mathrm{~km}$ ) a függőleges konténerkezelési technológiák nem képesek megszüntetni. Ennek következménye, hogy a magyarországi belföldi intermodális vasúti-közúti áruszállítás aránya nagyon alacsony, 2-3 \% körül van. Ennek ellenére a hazai beruházók, illetve termináltervezéssel 
foglalkozó szakemberek - a gyakorlati példák alapján megállapítható, hogy - nem nyitottak az új megoldásokra.

\section{Horizontális átrakási technológia}

Az elmúlt húsz évben számos intermodális áruszállítás fejlesztésére vonatkozó innováció született az intermodális szállítás piaci részesedésének növelése érdekében [6]. Ennek ellenére a vasúti áruszállításban, illetve az intermodális szállításban érdekelt szakemberek érdeklődését szerény mértékben sikerült felkelteni. Az alábbiakban néhány példa látható a horizontális konténerkezelési technológiát alkalmazó új fejlesztésủ konténerkezelési eljárásokra vonatkozóan.

A vízszintes konténer átrakásnak azt nevezzük, amikor kis emelési magassággal történik az átrakás, és többségében alkalmazható vasúti felső vezeték alatt is. Ez utóbbi tulajdonság a meghatározó a függőleges konténer átrakáshoz képest. A 3. és a 4. ábrákon látható berendezéseknek a fejlesztése 1997-2000 között, a svájci vasút (SBB) aktív részvételével történt [7].

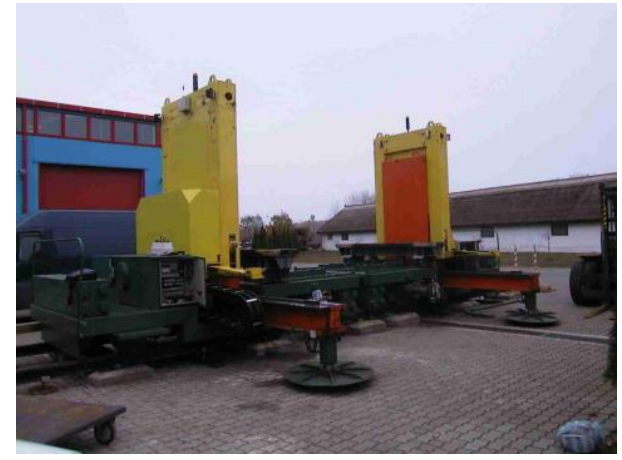

3. ábra KORAX-MIKON RTS 501 [8]

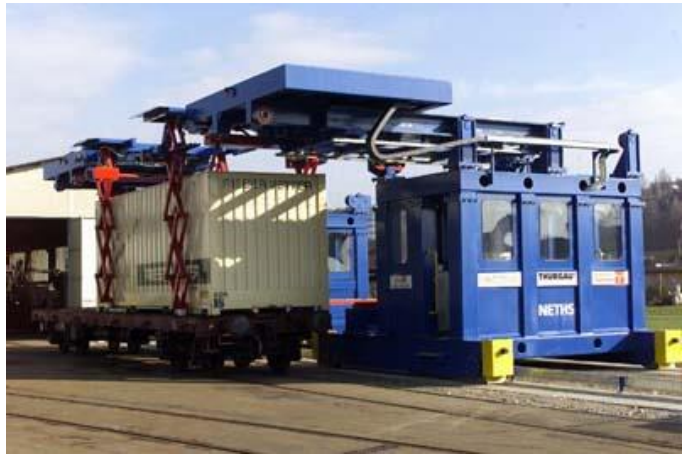

4. ábra NETHS [9]

A 3. ábrán látható berendezés esetében hátrányként a következőket szükséges kiemelni:

- az átrakónak és a kamionnak párhuzamosnak kell lennie,

- nem alkalmas halmozásra,

- nem kezeli a csereszekrényeket,

- a konténer oldalsó megfogása nem szabványos.

A 4. ábrán bemutatott berendezés esetében hátrányként fogalmazható meg, hogy nem alkalmas halmozásra, nem szabványos vasúti sínen mozog, valamint a felső vezetéktől a távolság nem elég biztonságos.

A 3. és a 4. ábrákon látható berendezéseknek csak prototípusa ismert. A fóbb müszaki követelményeket a berendezések kielégítették ugyan, de további fejlesztésük nem ismert.

Az Innovatrain cég ContainerMover technológiája hasonlít a Mobiler rendszerhez, azzal az eltéréssel, hogy nincs szükség speciális konténer konstrukcióra. A fentiekben bemutatott horizontális átrakodási technológiák közös hátránya, hogy a vasúti kocsi és a közúti szállító jármü egyidejü jelenlétét igénylik. Jellemző alkalmazásuk az irányvonatokkal kiszolgált áruáramlási folyamatokban lehetséges. A Mobiler (5. ábra) és az ACTS rendszerek (6. ábra) alkalmasak lehetnek a zárt logisztikai lánc kiszolgálására. Néhány esetben az ÖBB-nél van példa az alkalmazásukra. 


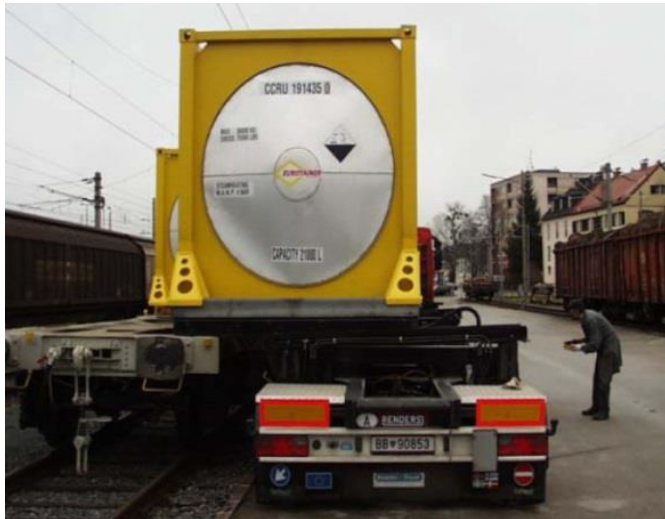

5. ábra Mobiler [10]

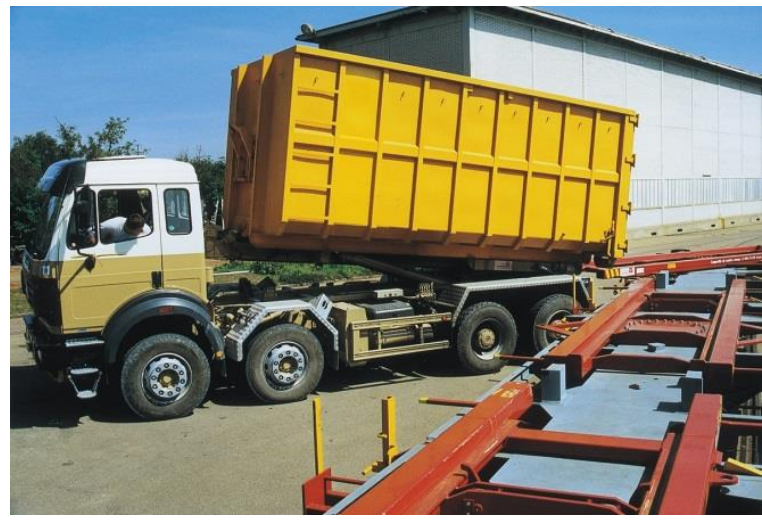

6. ábra ACTS [9]

A Mobiler esetében hátrányt jelent, hogy alkalmazásához speciális konténer és speciális közúti jármü szükséges, továbbá a vasúti vagont ki kell egészíteni.

Az ACTS rendszereknél hátrányként fogalmazható meg, hogy alkalmazásukhoz speciális vasúti kocsi, speciális gépkocsi és speciális konténer szükséges (ömlesztett anyagokhoz).

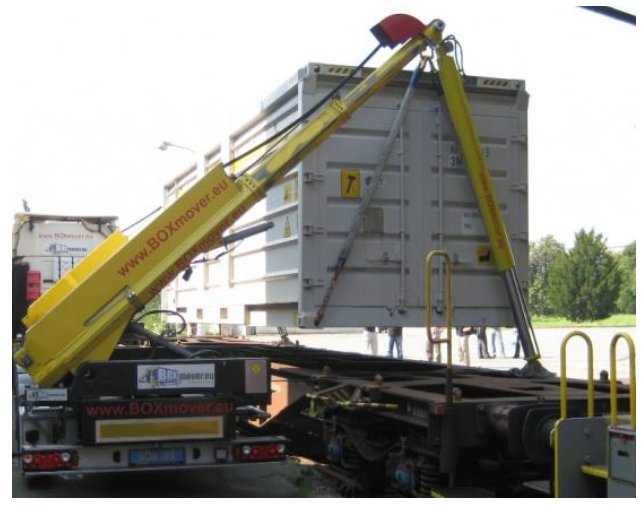

7. ábra BOXmover [11]

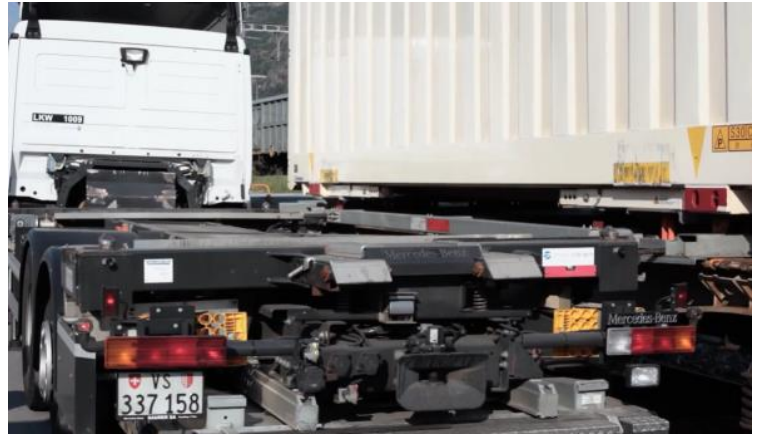

8. ábra ContainerMover [12]

A BOXmover esetében hátrányként a következőket szükséges kiemelni:

- speciális tehergépkocsit igényel,

- a kezelönek sok feladatot kell elvégeznie,

- az átrakási idő viszonylag hosszú,

- egymás mellett álló konténerek nem emelhetőek.

A ContainerMover esetében hátrányként fogalmazható meg, hogy speciális tehergépkocsit igényel és átalakított vasúti vagon szükséges az alkalmazásához.

A 7. és a 8. ábrákon látható berendezéseknek ugyancsak prototípusa ismert. Ezekben az esetekben sincs ismeret a rendszerek szélesebb körü alkalmazásáról.

A 9. ábrán bemutatott berendezés esetében hátrányként fogalmazható meg, hogy csak egy oldal kiszolgálására képes, valamint felsővezeték alatt korlátozottan alkalmazható. 


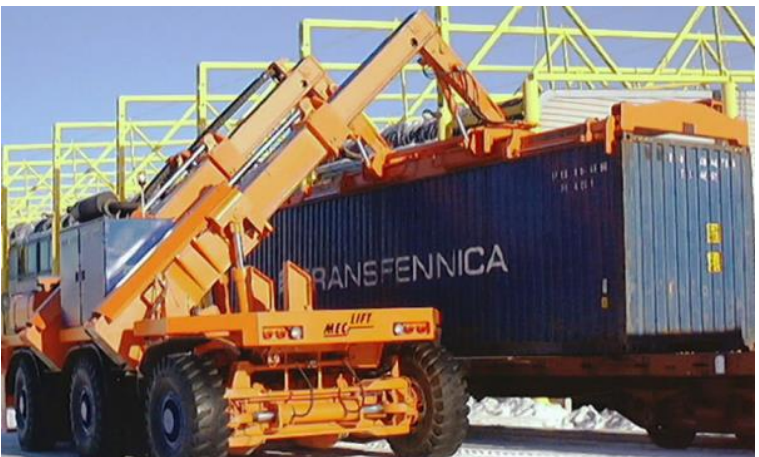

9. ábra Meclift ML5016SR [13]

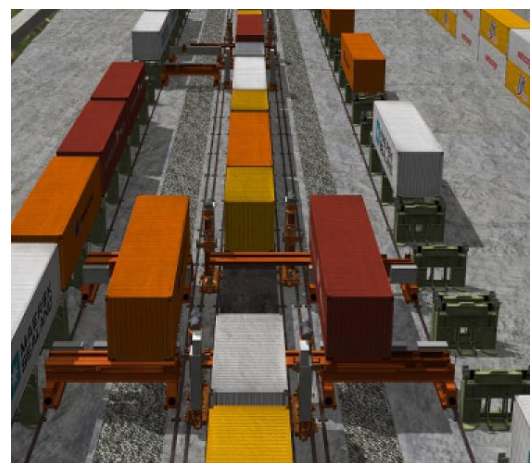

10. ábra Metrocargo [14]

A Metrocargo esetében hátrányként a következöket szükséges kiemelni:

- a vasúti pálya mindkét oldalára emelő eszközt kell építeni,

- a gépkocsira rakáshoz a gépkocsi mindkét oldalára emelőeszközt kell kialakítani,

- nem képes halmozásra.

A fenti horizontális konténer átrakási eljárások közül a 9. ábrán látható Meclift nem alkalmazható felső vezeték alatt mivel a gumikerekes konténer emelökhöz hasonló megfogó szerkezete (sprider) szerkezeti magassága jelentősen csökkenti a biztonsági távolságot. A 10. ábra szerinti Metrocargo rendszer vagon és átmenti tároló közötti átrakást biztosít.

\section{Korszerü horizontális átrakási követelmények}

A fentebb ismertetett, intermodális vasúti-közúti áruszállítás szemszögéből vázolt problémák müszakitechnológiai oldalról megoldhatóak. Az ismert függőleges és horizontális konténer átrakást megvalósító berendezések konstrukciójának vizsgálata, valamint a vasúti-közúti intermodális szállítás követelményeit felmérve meghatározhatóak azok a föbb funkcionális követelmények, melyeket ki kell a hatékony konténer átrakó berendezésnek elégíteni. Felsorolásszerủen az alábbi funkcionális követelményeket kell kielégíteni:

- vasúti felső vezeték alatti biztonságos alkalmazhatóság,

- ISO és csereszekrények átrakására egyaránt képesnek kell lennie,

- elektromos üzemú legyen a környezetvédelmi célok érdekében,

- részben, vagy egészében automatikus üzemre (kezelő nélküli) legyen képes.

A jelenlegi szabályok szerint feszültség alatti vasúti felsővezeték alatt semmilyen konténerkezelés nem végezhető. Ha a szabály nem változtatható meg, akkor az átrakó szakasz felsővezetékének szakaszolásával, azt az átrakás idejére feszültség mentesíteni kell.

\section{Köszönetnyilvánítás}

A cikkben ismertetett kutató munka az EFOP-3.6.1-16-2016-00011 jelü „Fiatalodó és Megújuló Egyetem - Innovatív Tudásváros - a Miskolci Egyetem intelligens szakosodást szolgáló intézményi fejlesztése" projekt részeként - a Széchenyi 2020 keretében - az Európai Unió támogatásával, az Európai Szociális Alap társfinanszírozásával valósul meg. 


\section{Felhasznált irodalom}

[1] Behrends, S., Flodén, J. The effect of transhipment costs on the performance of intermodal linetrains. Logistic Resurces 2012, 4:127-136. https://doi.org/10.1007/s12159-012-0066-0.

[2] Woxeniusa, J., Andersson, E., Bärthela, F., Trocheb, G., Sommar, R., Trouvè, J. A Swedish intermodal transport service based on line-trains serving freight forwarders. Conference: World Conference on Transport Research, Istanbul 2004. Available at: https://www.researchgate.net/publication/237557591

[3] Sommar R., Woxenius, J. Time perspectives on intermodal transport of consolidated cargo. European Journal of Transport and Infrastructure Research 2007, 2:163-182.

[4] https://youtube/Jcsm3TMT_nM

[5] www.kalmarglobal.com

[6] Hansen, I.A. Automated shunting of rail container wagons in ports and terminal areas. Available at: https://www.researchgate.net/publication/296375739

[7] INHOTRA. Final Report. Available at: https://trimis.ec.europa.eu/sites/default/files/project/documents/20060727_150345_76487_INHO TRA_Final_Report.pdf

[8] www.loxodon.com/en/node/4

[9] Lewandowski, K. The ACTS system a chance for the rail transport on increase in the intermodal transport. ANALIZY. 06. may. 2015., Rynek Kolejowy ISSN 1644-1958, pp.104-107. Available at: https://www.researchgate.net/publication/275948340

[10] www.mobiler.info

[11] https://commons.wikimedia.org/wiki/File:Seitenlader_ISO_Containerumschlag_auf_Tragwaggon -.jpg

[12] www.innovatrain.ch

[13] www.hinrichs-forklifts.com

[14] https://metrocargoitalia.it/ 